\title{
Inter and intraspecific variation in nuclear DNA content in Aedes mosquitoes
}

\author{
P. Nagesh Rao and \\ K. S. Rai
}

Department of Biological Sciences, University of Notre Dame, Notre Dame, IN 46556, U.S.A.

Haploid nuclear DNA of 23 species of Aedes, as determined by Feulgen cytophotometry, was found to vary 3-fold. This was accompanied by a 2 -fold variation in total chromosomal length. There was a significant correlation $(r=$ $0.765, P<0.001)$ between these two parameters. Genome size varied from $0.87 \mathrm{pg}$ to $1.3 \mathrm{pg}$ among 10 strains of Aedes albopictus, from wide geographic regions. Large scale differences in chromosomal DNA amounts have accompanied speciation and evolution in aedine mosquitoes.

\section{INTRODUCTION}

Amounts of nuclear DNA vary greatly among and within taxa (Bachman et al., 1972; Sparrow et al., 1972; Rees and Jones, 1972; Hinegardner, 1976; Sherwood and Patton, 1982). For example, the genome sizes of several Drosophila species show a 2.5-fold variation in C-values (Laird, 1973). Similarly Rees et al. (1978) observed a 3-fold variation in nuclear DNA content among species of acridid grasshoppers with uniform karyotype. Bier and Muller (1969) measured the genome sizes of a variety of insects and found that primitive groups have larger genomes than more recently evolved insect groups. In mosquitoes, very little work has been done in this field. Jost and Mameli (1972) and Spradling et al. (1974) have provided some data on relative and absolute amounts of DNA in two species of Aedes and six species of three other genera.

The genus Aedes (Culicidae) is subdivided into 38 subgenera (Knight and Stone, 1977) and includes more than 1000 species (White, 1980). One of the largest subgenera, Stegomyia, contains about 110 described species divided into seven groups including the scutellaris group which is subdivided into the scutellaris and albopictus subgroups. Ae. scutellaris subgroup is widely distributed in Southeast Asia and the South Pacific (Marks, 1954; Huang and Hitchcock, 1980), and has a predominantly allopatric distribution; on the other hand the albopictus subgroup has largely sympatric distribution over a wide range stretching from Madagascar in the west through the IndoMalayan and the Oriental regions, China, Japan, the Pacific islands and extending as far east as Hawaii, and is recently reported to be in southern United States (Knight and Stone, 1977; Rai, 1987). Both these subgroups have been the object of extensive genetic studies with particular emphasis on the genetics of speciation (Rai, 1983; Rai, 1987).

A striking cytological feature of Aedes is the constancy in the chromosome number $(2 n=6)$ and the lack of pronounced variation in chromosome morphology among various species (Rai et al., 1982; Rao, 1985). Most species so far studied are characterised by a small pair of metacentric chromosome and two pairs of larger metacentric or submetacentric chromosomes. However, careful measurements of chromosomal arms, giemsa Cbanding studies, meiotic analyses of species hybrids and linkage map comparisons have shown the existence of individual differences among the karyotypes of various species (Rai, 1980; Dev and Rai, 1984; Sherron and Rai, 1984; Rao and Rai, 1987). The uniformity in the chromosome number and yet the worldwide distribution and habitat diversity of various species, make Aedes an interesting genus to study the extent of changes in nuclear DNA amount and its possible evolutionary role.

Feulgen cytophotometry is an important investigative technique to determine quantitative genomic changes across and within species. This 
paper presents data on nuclear DNA in (a) 23 species of Aedes, belonging to five subgenera with different distribution and habitat preferences, with particular emphasis on the Aedes scutellaris group, and (b) 10 geographic strains of the widespread species Ae. albopictus. Other objectives of this study were to correlate total chromosomal length to nuclear DNA amounts in order to ascertain the evolution of chromosomal DNA between and within species and to provide information on which to base future analyses of genome organisation.

\section{MATERIALS AND METHODS}

Table 1 provides the names of the 23 species with the sites and dates of their original collection. Field collected species were raised at $21^{\circ} \mathrm{C}$ in the laboratory. The rest of the species were reared in the insectary maintained at $25 \pm 2^{\circ} \mathrm{C}$ and $80 \pm 10$ per cent relative humidity (Craig and Vande Hey, 1963).

Testes from $12-24 \mathrm{~h}$ old male pupae, were dissected in insect saline, fixed in formalin-acetic acid-ethanol (6:1:14) (Sharma and Sharma, 1980), and squashed in 45 per cent acetic acid. Each slide also contained on one side a fine smear of chicken red blood cells (Dhillon et al., 1977).

For Feulgen staining, the tissue was hydrolysed in $5 \mathrm{~N} \mathrm{HC1}$ for $30 \mathrm{~min}$ at room temperature and washed throughly in cold running water. Staining was done in Schiff's reagent for $1 \mathrm{~h}$ and excess stain was washed off with three rinses in aq. 10 per cent potassium metabisulphite solution (McLeish and Sunderland, 1961).

Relative feulgen units were calculated according to Patau (1952), using the two-wavelength method $(505 \mathrm{~m}$ and $555 \mathrm{~nm}$, determined through absorbance versus wavelength curve) (Berlyn and Mikshe, 1976), with a Zeiss Microscope Photometer 01 . Thirty to fifty primary spermatocytes at

Table 1 Taxonomy and source of species and strains of Aedes examined

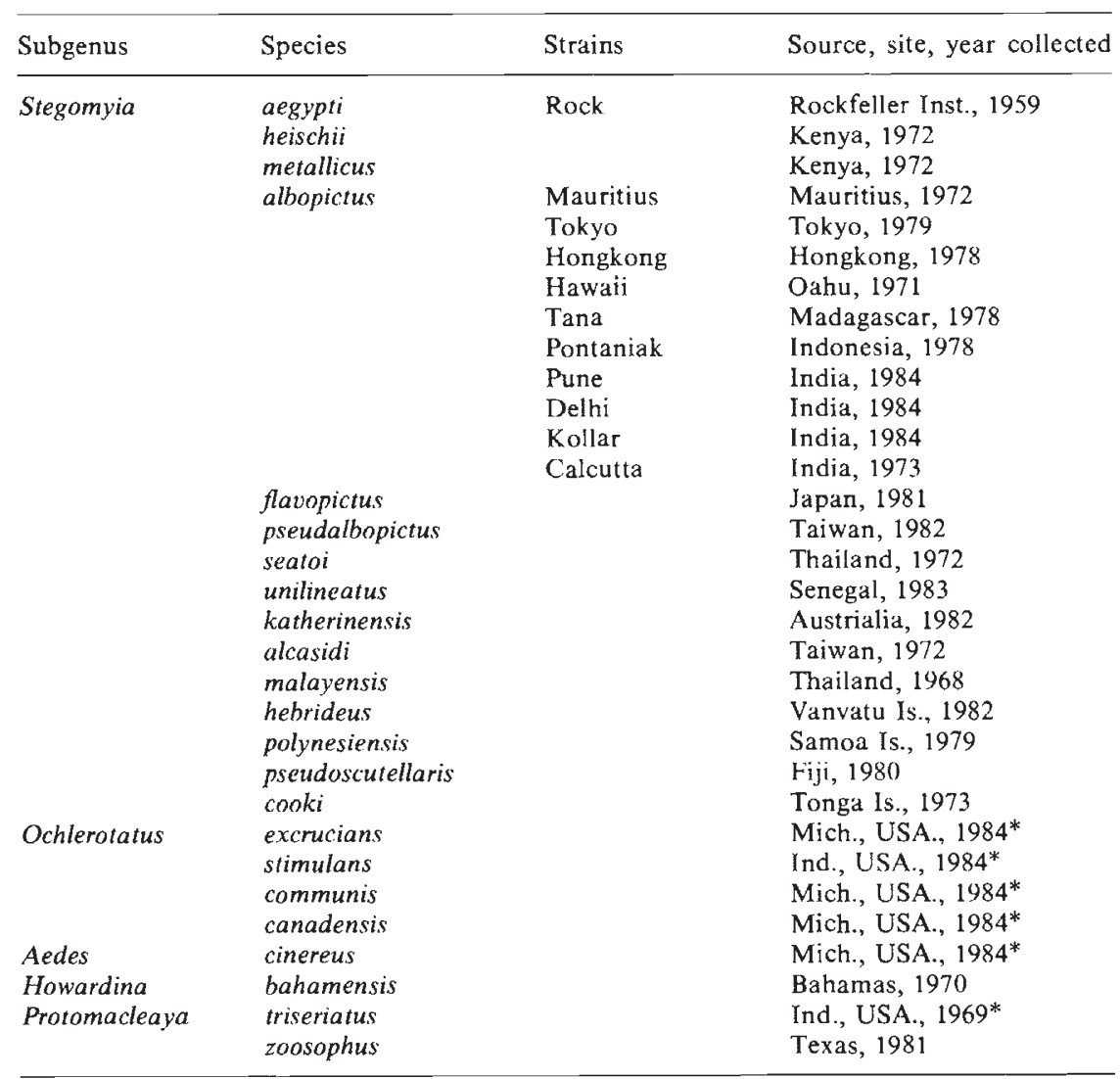

\footnotetext{
* Field collected
} 
metaphase I, were scored from a total of three to five pupae. In most cases anaphase I cells were also measured from the same slide to confirm the values obtained for the metaphases. The chick erythrocytes stained simultaneously not only served as an internal standard for the day to day variations but the values were also used to convert relative mosquito DNA values to absolute amounts in picograms (pg), using $2.5 \mathrm{pg}$ per nucleus as the value for the diploid chicken genome (Mirsky and Ris, 1951; Leslie, 1955; Rasch et al., 1978). All DNA amounts reported are 1C values or values of the unreplicated haploid complement.

A One-Way ANOVA with absolute DNA values as the response variable and the different species and strains as the treatment was performed. Duncan's Multiple Range Test was used to compare mean DNA values of some species and to establish different groupings.
Total chromosomal length measurements at somatic metaphases were obtained according to the procedure described by Rao and Rai (1987).

\section{RESULTS}

Haploid DNA amounts (1C) of the 23 Aedes species, the total chromosomal length of 18 species, and the results of the Duncan's Test are shown in table 2. The ANOVA was significant at the $P<$ 0.001 level.

In the aegypti group, the rock strain of Ae. aegypti possessed $0.812 \pm 0.031 \mathrm{pg}$ of haploid DNA. Among the seven species examined in the scutellaris subgroup, Ae. katherinensis with 1.277士 $0.02 \mathrm{pg}$ had the highest $1 \mathrm{C}$ nuclear DNA per cell. It was approximately double the amount found in Ae. pseudoscutellaris and Ae. cooki which

Table 2 Absolute 1C nuclear DNA amounts and total chromosomai length

\begin{tabular}{|c|c|c|c|c|}
\hline Species/strains & DNA (pg) & S.E. ${ }^{a}$ & $\begin{array}{l}\text { Duncan's } \\
\text { groups }^{b}\end{array}$ & $\operatorname{TCL}(u)^{\mathrm{c}}$ \\
\hline aegypti & $0 \cdot 812$ & 0.03 & & $19 \cdot 90^{\mathrm{d}}$ \\
\hline heischii & $1 \cdot 121$ & $0 \cdot 03$ & & $21 \cdot 62$ \\
\hline metallicus & $1 \cdot 093$ & $0 \cdot 03$ & & $19 \cdot 32$ \\
\hline \multicolumn{5}{|l|}{ albopictus } \\
\hline Mauritius & $1 \cdot 321$ & 0.03 & A & $26 \cdot 91$ \\
\hline Tokyo & $1 \cdot 286$ & 0.03 & A & \\
\hline Hong Kong & $1 \cdot 259$ & 0.03 & A & \\
\hline Oahu & $1 \cdot 239$ & 0.03 & A B & $21 \cdot 23$ \\
\hline Tana & $1 \cdot 148$ & 0.02 & B C & $31 \cdot 10$ \\
\hline Pontaniak & $1 \cdot 068$ & 0.04 & $\mathrm{C}$ & \\
\hline Pune & $1 \cdot 066$ & 0.06 & $\mathrm{C}$ & $31 \cdot 95$ \\
\hline Delhi & $1 \cdot 021$ & 0.01 & $\mathrm{CD}$ & 32.85 \\
\hline Kollar & 0.944 & 0.03 & D & $24 \cdot 07$ \\
\hline Calcutta & 0.865 & 0.03 & $\mathrm{D}$ & $23 \cdot 99$ \\
\hline flavopictus & $1 \cdot 330$ & 0.02 & & $33 \cdot 34$ \\
\hline pseudalbopictus & $1 \cdot 290$ & 0.02 & & 30.09 \\
\hline unilineatus & $1 \cdot 064$ & 0.04 & & $25 \cdot 50$ \\
\hline seatoi & 0.971 & $0 \cdot 02$ & & $27 \cdot 11$ \\
\hline katherinensis & $1 \cdot 277$ & 0.02 & A & $29 \cdot 51$ \\
\hline alcasidi & 0.974 & 0.02 & B & $21 \cdot 44$ \\
\hline malayensis & 0.943 & 0.03 & $\mathrm{~B}$ & $19 \cdot 12$ \\
\hline hebrideus & 0.965 & 0.03 & B & $19 \cdot 33$ \\
\hline polynesiensis & 0.725 & 0.02 & $\mathrm{C}$ & $20 \cdot 88$ \\
\hline cooki & $0 \cdot 594$ & 0.03 & $\mathrm{D}$ & \\
\hline pseudocutellaris & 0.591 & 0.01 & $\mathrm{D}$ & $16 \cdot 24$ \\
\hline excrucians & $1 \cdot 500$ & 0.03 & & \\
\hline stimulans & 1.439 & 0.04 & & $29 \cdot 80^{d}$ \\
\hline communis & 1.013 & 0.05 & & \\
\hline canadensis & 0.904 & 0.02 & & \\
\hline cinereus & $1 \cdot 210$ & 0.03 & & $21 \cdot 80^{\mathrm{e}}$ \\
\hline bahamensis & $1 \cdot 375$ & 0.03 & & \\
\hline triseriatus & $1 \cdot 520$ & 0.06 & & $35 \cdot 88$ \\
\hline zoosophus & $1 \cdot 902$ & 0.06 & & $38 \cdot 29$ \\
\hline
\end{tabular}

${ }^{\mathrm{a}} \mathrm{S} . \mathrm{E} .=$ standard error; ${ }^{\mathrm{b}} \mathrm{P}<0.001 ;{ }^{\mathrm{c}} \mathrm{TCL}=$ total chromsome length in microns; ${ }^{\mathrm{d}}$ Rai (1963);

${ }^{e}$ Mukherjee et al. (1970). 
possessed the smallest genome of all Aedes examined. Ae alcasidi, Ae malayensis and Ae. hebrideus were grouped together and did not differ significantly in their DNA amounts. The 10 strains of Ae. albopictus ranging from Hawaii to Mauritius had 1C DNA amounts ranging from $1 \cdot 321 \pm$ $0.035 \mathrm{pg}$ to $0.865 \pm 0.03 \mathrm{pg}$. Duncan's Test established six groupings based on genome sizes with some overlapping. Both Ae. triseriatus and Ae. zoosophys of the subgenus Protomacleaya, with $1.52 \pm 0.062 \mathrm{pg}$ and $1.902 \pm 0.062 \mathrm{pg}$ respectively have the highest DNA values of all aedine species studied here.

Linear regression analysis of the DNA amounts to the total chromosomal length of 18 species showed a significant correlation $(r=0.765 ; P<$ 0.001) (fig. 1).

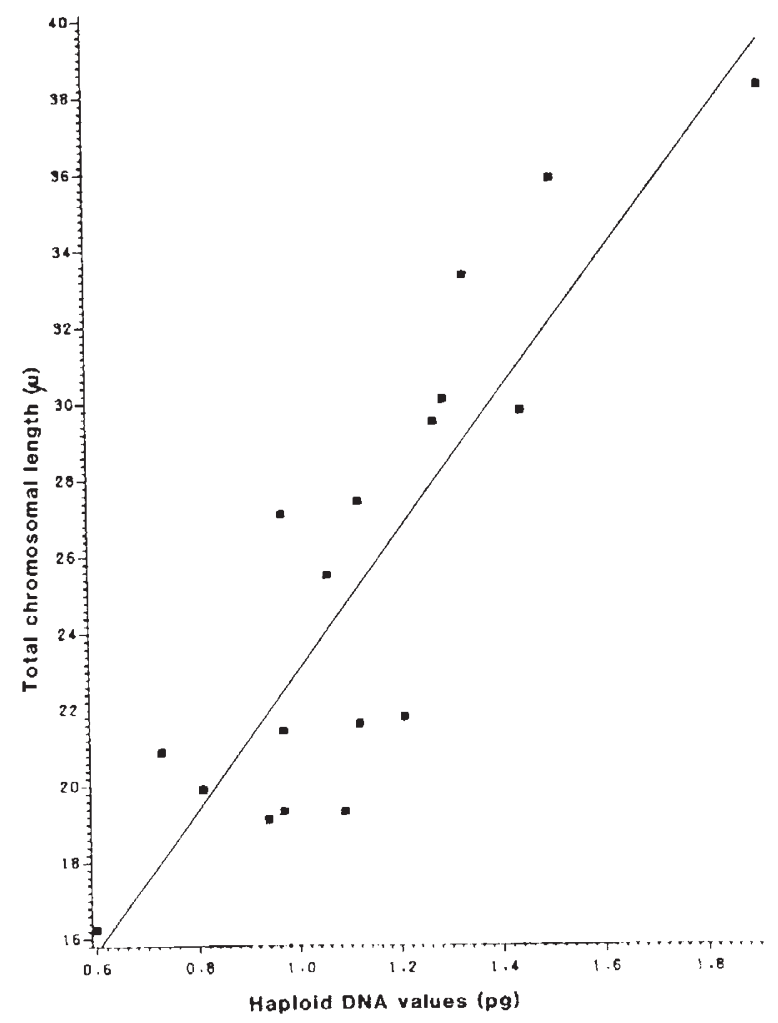

Figure 1 Linear regression of haploid DNA amounts to the total chromosomal length in 18 species of Aedes.

\section{DISCUSSION}

A three-fold variation in haploid DNA genome sizes was found among the 23 species of Aedes. In general, there was no correlation between DNA amounts and their systematic affinities. Also, this variation was accompanied by a two-fold range in the total chromosomal lengths at somatic metaphases. This increase in chromosomal size was often observed in all the three pairs of chromosomes, rather than one particular pair (Rai, 1963; Dev and Rai, 1984; Sherron and Rai, 1984; Rao and Rai, 1987). There was a good correlation between the DNA amounts and the total chromosomal lengths (fig. 1).

Based on biogeographical and morphological considerations, Belkin (1962) had originally suggested that speciation in the Ae. scutellaris subgroup proceeded from east to west with the southeast Asian species being of more recent origin and Polynesian species more primitive. This has been confirmed by other lines of research (Rai, 1983). Our results show that island dwelling species in Polynesia possessed low DNA amounts whereas the continental southeast Asian species had higher DNA values. This suggests that there has been a gradual amplification of chromosomal DNA in the evolution of species in this subgroup.

The mean nuclear DNA amount in the albopictus subgroup was higher than the scutellaris subgroup. Ae. flavopictus and Ae. pseudalbopictus had larger genomes and showed good pairing of chromosomes at metaphase 1 in their hybrids. In contrast, crosses between $A e$. seatoi, with a relatively smaller genome and Ae. flavopictus showed chromosomal size heteromorphism in two of the three pairs (Rai and Herman, 1985). The same was observed between Ae. seatoi and Ae. unilineatus.

The actual patterns of quantitative change within the Ae. albopictus strains was interesting. The Indo-Malayan region, where Ae. albopictus is widely distributed, is presumably the center of its origin. Strains from this region possess relatively lower DNA amounts. The expansion of the species to the various island regions is apparently associated with increase in nuclear DNA amounts. Similar correlation exists between nuclear genome sizes and historical migration of the species in the Ae. scutellaris subgroup. The nearly two-fold variation in DNA amount observed in strains of $A e$. albopictus demonstrates the presence of extensive populational difference in cellular DNA. The role it may play in its divergence is not well understood. Black and Rai (1987) showed that increase in DNA amounts in different strains was primarily due to higher amounts of highly repeated elements, although they found that in general all three classes of repeated DNA increased with genome sizes. Numerous studies have identified similar intraspecific variation in genome size in other taxa (Sherwood and Patton, 1982; Greenlee et al., 1984). It 
is possible that these differences arise within species and subsequently lead to or enhance divergence and speciation (Robertson, 1981). It is also well known that intrachromosomal addition of DNA within and between species have little effect on phenotypic or genotypic characters (Hutchinson et al., 1979, Sherwood and Patton, 1982).

The four species in the Ochleratus subgenus, had larger genome sizes and exhibited a 66 per cent difference in DNA content. The total chromosomal length of Ae. stimulans was the largest among the species reported by Rai (1963). Ae. caspius, a related species of the same subgenus, found in saline waters, was reported to have an haploid amount of $0.99 \mathrm{pg}$ (Jost and Mameli, 1972). Ae. triseriatus and Ae. zoosophus are somewhat specialised in their habitat preferences in that both are tree-hole mosquitoes.

There are numerous reports of large scale differences in the nuclear DNA content in related species (Hinegardner, 1976; Bennett and Smith, 1976). Britten and Davidson (1971), suggested that DNA increases are important in the origin of repetitive DNA which in turn may play a role in evolutionary diversification. In Dermestes, Fox (1969) reported significant differences in nuclear DNA despite very similar karyotypes. The variation in the total DNA content was mostly accounted for by variation in the fast fraction, that is made up largely of highly repetitive DNA (Rees et al., 1976). Using dot-hybridisation for nine clones of highly repeated elements from species of Ae. scutellaris subgroup, McLain et al. (1986) found that these elements varied greatly in their relative abundance among closely related species. This suggests that there are indeed differences in the amounts of repetitive DNA in the different species.

Spradling et al. (1974) examined the annealing properties of ribosomal, hnRNA and messenger RNA to DNA in vast excess in mammalian and Ae. albopictus cell lines. They found that the mosquito cell line had 3.5-fold less DNA than the mammals. The range for mammalian haploid genome is $3-5.8 \mathrm{pg}$ (Hinegardner, 1976). This compares with 0.86-1.66 pg for the Ae. albopictus cell line. The mean for Ae. albopictus obtained in our study is about $1 \cdot 12 \mathrm{pg}$ which fits very well with their results. The amount of DNA in the genome has been correlated with several variables, such as length of the mitotic cycle (Van 't Hof and Sparrow, 1963) and the minimum length of generation time (Smith and Bennett, 1975). When the generation time from the early larval stage to adult was studied in the Ae. alobopictus strains, there was a significant correlation between the haploid DNA amounts and the developmental time (Ferrari and Rai, unpublished).

Based on DNA amounts it was suggested that organisms (Chironomus, $0.2 \mathrm{pg} /$ haploid genome [Wells et al., 1976]; Apis mellifera, $0.35 \mathrm{pg} /$ haploid genome [Crain et al., 1976b]), with low DNA amounts (less than $0.4 \mathrm{pg}$ ) would show the Drosophila-type of longterm interspersion of repeats while those with larger genomes (Musca, $0.89 \mathrm{pg} /$ haploid genome [Crain et al., 1976 b], will exhibit quite typical short-term repeat pattern the Xenopus-type. With Aedes showing such extensive variation in DNA amounts it would be interesting to study the pattern of repeated elements in this large genus. Black and Rai (1987) found that genomic organisation in Ae. albopictus and Ae. triseriatus was of the short interspersed type.

In conclusion, large scale differences in chromosomal DNA amounts have accompanied speciation and evolution in Aedes besides structural changes brought about by chromosomal rearrangements (Munstermann, 1981; Rai et al., 1982).

Acknowledgment We thank Drs W. Black and J. Ferrari for their help in numerous ways. This research received support from NIH grant 5R01 AI 21443 to K. S. Rai.

\section{REFERENCES}

BACHMAN, K., GOIN, O. B. AND GOIN, C. J. 1972. Nuclear DNA amounts in vertebrates. Brookhaven Symp. Biol., 23, 419450.

BELKIN, J. N. 1962. The mosquitoes of the South Pacific (Diptera: Culicidae), vol. I-II. Univ. of California Press, Berkeley.

BENNETT, M. D. AND SMITH, J. B. 1976. Nuclear DNA amounts in angiosperms. Phil. Trans. Roy. Soc. Lond. B., 277, 201226.

BERLYN, G. P. AND MIKSCHE, J. P. 1976. Botanical Microtechniques and Cytochemistry. The Iowa State Univ. Press, Ames.

BIER, V. K. AND MULLER, W. 1969. DNA-Messungen bei Insekten und eine hypothese über retardierte Evolution und besonderen DNS-Reichtum in Tierreich. Biol. Zentralbl., $88,425-449$.

BLACK, W. AND RAI, K. S. 1987. Genome evolution in mosquitoes: intra- and interspecific variation in repetitive DNA amounts and organization. (submitted)

BRITTEN, R. J. AND DAVIDSON, E. H. 1971. Repetitive and non-repetitive DNA sequences and a speculation on the origins of evolutionary novelty. Quart. Rev. Biol., 46, 111138.

CRAIG, G. B. AND VANDE HEY, R. C. 1962. Genetic variability in Aedes aegypti. I. Mutations affecting color patterns. Ann. Entomol. Soc. Amer., 55, 47-58.

CRAIN, W. R., DAVIDSON, E. H. AND BRITTEN, R. J. $1976 \mathrm{~b}$. Contrasting patterns of DNA sequence arrangement in Apis mellifera (honey bee) and Musca domestica (house fly). Chromosoma, 59, 1-12. 
DEV, V. AND RAI, K. S. 1984. Genetics of speciation in the Aedes (Stegomyia) scutellaris group (Diptera: Culicidae). V. Chromosomal relationship among five species. Genetica, $64,83-92$.

DHILLON, S. S., BERLYN, G. P. ANI MIKSC:HE, J. P. 1977. Requirement of an internal standard for microspectrophotometric measurements of DNA. Amer. J. Bot., 64, 117-121.

FOX, D. P. 1969. The relationship between DNA value and chromosome volume in the coleopteran genus Dermestes. Chromosoma, 27, 130-144.

GREENLEE, J. K., RAI, K. S. ANI) FLOYD, A. D. 1984. Interspecific variation in nuclear DNA content in Collinsia verna Nutt. (Scrophulariaceae). Heredity, 52, 235-242.

HINEGARDNER, R. 1976. Evolution of genome size. In Ayala, F. J. (ed.) Molecular Evolution. Sinauer Assoc., Inc. Sunderland.

HUANG, Y. M. AND HITCHCOCK, J. C. 1980. A revision of the Aedes scutellaris group of the Tonga (Diptera: Culicidae). Contrib. Am. Entomol. Inst., 17, 1-107.

HUTCHINSON, J., REES, H. AND SEAL, A. G. 1979. An assay of the supplementary DNA in Lolium. Heredity, 43, 411-421.

JOST, E. AND MAMELI, M. 1972. DNA content in nine species of Nematocera with special reference to the sibling species of the Anopheles maculipennis group and the Culex pipiens group. Chromosoma, 37, 201-208.

KNIGHT, K. L. AND STONE A. 1977. A catalog of the mosquitoes of the world (Diptera: Culicidae). Entomol. Soc. Am., 2nd ed.

LAIRD, C. D. 1973. DNA of Drosophila chromosomes. Ann. Rev. Genet., 7, 177-204.

LESLIE, I. 1955. The nucleic acid content of tissues and cells. In Chargaff, E. and Davidson, J. N. (eds.) The Nucleic Acids, vol. 2, Academic Press, New York.

MARKS, E. N. 1954. A review of the Aedes scutellaris subgroup with a study of variation in Aedes pseudoscutellaris (Theobald). Bull. Brit. Mus. (Nat. Hist.) Entomol., 3, 349414.

MCLAIN, D. K., RAI, K. S. AND FRASER, M. J. 1986. Interspecific variation in the abundance of highly repeated DNA sequences in the Aedes scutellaris (Diptera: Culicidae) subgroup. Ann. Entomol. Soc. Am., 79, 784-791.

MCLEISH, J. AND SUNDERLAND, N. 1961. Measurements of deoxyribonucleic acid [DNA] in higher plants by feulgen photometry and chemical methods. Exp. Cell Res., 24, 527-540.

MIRSKY, A. E. AND RIS, H. 1951. The deoxyribonucleic acid content of animal cells and its evolutionary significance. J. gen. Physiol., 34, 451-462.

MUKHERJEE, A. B., REES, D. M. AND MUKHERJEE, A. B. 1970. A comparative study of the mosquito karyotypes. C.ytologia, 35, 57-62.

MUNSTERMANN, 1.. r. 1981. Enzyme linkage maps for tracing chromosomal evolution in Aedes mosquitoes. In Stock, M. W. (ed.) Application of genetics and cytology in insect systematics and evolution. University of Idaho, Moscow.

PATAU, K. 1952. Absorption microphotometry of irregular shaped objects. Chromosoma, 5, 341-362.

RAI, K. S. 1963. A comparative study of mosquitoes karyotypes. Ann. Entomol. Soc. Am., 56, 160-170.

RAI, K. S. 1980. Evolutionary cytogenetics of Aedine mosquitoes. Genetica, 52/53, 281-290.
RAI, K. S. 1983. Genetics and chromosomal differentiation in the Aedes (Stegomyia) scutellaris group. Proc. Int. Cong. Genetics, vol. III, 99-11.

RAI. K. S. 1987. Genetical differentiation in Ae. albopictus. J. Am. Mosq. Control. Assoc. 2, 429-436.

RAI, K. S. AND HERMAN, G. 1985. Genetic relationships among five species in Aedes (Stegomyia) albopictus subgroup. Annual Meetings of Genetics Soc. of America. Abstract.

RAI, K. S., PASHLEY D. P. AND MUNSTERMANN, L. E. 1982. Genetics of speciation in aedine mosquitoes. In Steiner, W. M. M., Tabachnick, W. J., Rai, K. S. and Narang, S. (eds.) Recent developments in genetics of insect disease vectors. Stipes Publ., Champaign.

RAO, P. N. 1985. Nuclear DNA and chromosomal evolution in mosquitoes. Ph.D. Thesis, University of Notre Dame.

RAO, P. N. AND RAI, K. S. 1987. Comparative karyotypes and chromosomal evolution in some genera of nematocerous (Diptera: Nematocera) families. Ann. Entomol. Soc. Am. (in press).

RASCH, E. M., BARR, H. J. AND RASC:H, R. W. 1978. The DNA content of sperm of Drosophila melanogaster. Chromosoma, $33,1-18$.

REIS, H. ANI) JONF.S, R. N. 1972. The origin of wide species variation in nuclear DNA content. Int. Rev. Cytol., 32, 53-92.

REES, H., SHAW, ID. D. AND WILKSON, P. 1978. Nuclear DNA variation among acridid grasshoppers. Proc. Royal Soc. Lond., 202, 517-525.

REES, R. W., FOX, I. P. ANI MAHER, E. P. 1976. DNA content, reiteration and satellite in Dermestes. In Jones. $\mathrm{K}$. and Brandham, P. E. (eds.) Current Chromosome Research, North-Holland Publications, New York.

ROBERTSON, M. 1981. Gene families, hopeful monsters and the selfish genetics of DNA. Nature, 293, 333-334.

SHARMA, A. K. AND SHARMA, A. 1980. Chromosome techniques, Theory and Practice. Butterworths, London.

SHERRON, I). A. ANI) RAI, K. S. 1984. Genetics of speciation in Aedes (Stegomyia) scutellaris subgroup (Diptera: Culicidae). IV. Chromosomal relationships of Aedes cooki with four sibling species. Can. J. Genet. Cytol., 26, 237-248.

SHERWOOI), S. W. AND PATTON, J. L. 1982. Genome evolution in pocket gophers (Genus Thomomys). II. Variation in cellular DNA content. Chromosoma, 85, 163-179.

SPRADLING, A., PIENMAN, S., CAMPO, M. S. AND BISHOP, J. O. 1974. Repetitious and unique sequences in the heterogenous nuclear and cytoplasmic messenger RNA of mammalian and insect cells. Cell, 3, 23-30.

SPARROW, A. H., PRICI: H. J. AND UNDERBRINK, A. (i. 1972. A survey of DNA content per cell and per chromosome of prokaryotic and eukaryotic organisms: some evolutionary considerations. Brookhaven Symp. Biol, 23, 451-495.

VAN'T HOF, J. ANI) SPARROW, A. H. 1963. A relationship hetween DNA content, nuclear volume and minimum mitotic cycle time. P.N.A.S. USA, 49, 897-902.

WELLS, R., ROYI:R, H. D. AND HOILLENBERG, C. P. 1976. Non Xenopus-like DNA sequence organization in the Chironomus tentans genome. Molec. Genet., 147, 45-51.

WHITE, G. B. 1980. Academic and applied aspects of mosquito cytogenetics. In Blackman, R. L., Hewitt, G. M. and Ashhurner, M. (eds.) Insect Cytogenetics, Blackwell Scientific Publications, Oxford. 